\title{
BIOSYSTEMATIC STUDIES OF ELYMUS REPENS (L.) GOULD (POACEAE): PATTERNS OF PHENOTYPIC VARIATION
}

\author{
MAGDALENA SZCZEPANIAK \\ W. Szafer Institute of Botany, Polish Academy of Sciences, \\ Department of Vascular Plants Systematics \\ Lubicz 42, 31-512 Kraków, Poland \\ e-mail: M.Szczepaniak@botany.pl
}

(Received: May 7, 2008. Accepted: January 21, 2009)

\begin{abstract}
Inter- and intrapopulational morphological variability of Elymus repens, a cool-season perennial grass and a tenacious weed that spreads both by seeds and rhizomes forming a thick and stout net, was examined. Multivariate statistical analysis of 48 initial morphological characters obtained from 44 population samples (1180 specimens) collected in different habitats revealed the conspicuous variation within E. repens. Principal Component Analysis revealed three extremes of the morphological gradient that were referred to as three varieties of E. repens: var. repens, var. aristatus and var. subulatus, not correlated with the habitat type or geographical location. Canonical Discriminant Analysis proved the taxonomic usefulness of characters such as awned or awnless glumes and lemmas as well as the shape of glumes for variety distinction. Results of morphological analysis, in relation to the low level of genetic variation showed in the previous studies, suggest that the extensive morphological variation of E. repens can be caused by its plasticity where different morphological patterns are realized on the same genome basis. Additionally, the open-pollinated system of mating results in new combinations of morphological characters of plants that further reproduce vegetatively by rhizomes. The nomenclature, taxonomic descriptions and a key to the three varieties are provided.
\end{abstract}

KEY WORDS: Elymus repens, intraspecific variability, morphometrics, Poaceae, taxonomy.

\section{INTRODUCTION}

Elymus repens (L.) Gould [Syn.: Triticum repens L., Agropyron repens (L.) P. Beauv., Elytrigia repens (L.) Desv. ex Nevski], quackgrass, is a common, perennial grass considered to be one of the worst weeds worldwide (Holm et al. 1977). The species is native to entire Europe and Asia (Melderis 1980; Hultén and Fries 1986). Introduced to North America and South America, it also grows south of the tropic of Capricorn in South Africa (Bowden 1965; Tsvelev 1984). In Poland, the species occupies a wide range of habitats and is widespread throughout the entire area from lowlands to the mountain belt, occasionally surviving even above the timberline (Zając and Zając 2001). E. repens is a characteristic species of the Agropyretea intermedio-repentis class and the Agropyro-Rumicion crispi, a nitrophilous alliance that naturally occurs in damp habitats of pond banks and river banks, fields, and along forest roadsides (Matuszkiewicz 2005). Likewise, E. repens inhabits dry sandy sites or roadsides, waste tips, and anthropologically transformed sites or cultivated land (Falkowski 1982; Brej 2001; Szczepaniak 2002a).

Elymus repens s. lato is exceedingly morphologically variable and this characteristic has been used to distinguish intraspecific taxa at points along its broad geographic range (Szabó 1981; Prokudin 1982; Mizianty et al. 2001; Szczepaniak 2002a, b). Frequently, subspecies and many varieties or forms have been determined, mainly on the basis of the plant colour, the lengths of the culm, spike and spikelets, leaf width and pubescence as well as the presence or absence of the awns of glumes and lemmas (Fernald 1933; Melderis 1978; Löve 1984; Tsvelev 1984; Rothmaler 1994; Rutkowski 1998). In Flora Europaea, Melderis (1980) distinguished five subspecies of E. repens of which only subsp. repens occurs almost throughout entire Europe and is also a unique subspecies in Poland. The distribution of the other subspecies which are found in north-western Europe (subsp. arenosus), southern Europe (subsp. calcareus) and in Ukraine and Russia (subsp. pseudocaesius and subsp. elongatiformis) is limited. Additionally, Conert (1998) provided the findings on the occurrence of E. repens subsp. littoreus on the coast of the Mediterranean Sea and the Baltic Sea.

Elymus repens is an allohexaploid species $(2 \mathrm{n}=42)$ which arose in result of complex pattern of reticulate evolution by hybridization and introgression not only within Triticeae, but also from other divergent sources beyond the tribe (Mason-Gamer 2004). It is a highly self-sterile spe- 
cies, and cross-pollination is necessary for seed production (Taylor and Aarssen 1988). In its natural habitat, E. repens hybridizes at random with other species of the AgropyronElymus complex and also with representatives of other genera, e.g. Triticum L. and Hordeum L. (Hansen 1959; Mahelka et al. 2007; Szczepaniak et al. 2007).

In Polish studies of grasses, attention is paid to the great variability of Elymus repens (Mizianty et al. 2001); however, descriptions of intraspecific taxa are fragmentary and lack morphological details (Rostafiński 1873; Szafer 1919; Falkowski 1982; Rutkowski 1998). On the other hand, some authors do not even distinguish intraspecific taxonomic units within E. repens (Prokudin 1982; Kosina 1995). They regard it as an evolutionary young species whose high polymorphism is caused by numerous genome recombinations and mutations. Combined morphological and AFLP data were recently used to demonstrate that the genetic diversity of E. repens is considerably lower than its morphological variability which can be caused by vegetative reproduction by rhizomes, somatic mutations in particular ramets of one genet, and species plasticity (Kosina 1995; Szczepaniak et al. 2002; Szczepaniak and Cieślak 2003). However, preliminary morphological examinations focused only on selected populations and the continuum of morphological variation across this entire range was not studied in detail.

The main aim of the present study was (1) to analyse the morphological variation within Elymus repens s. lato on regional scale, i.e. in Poland, with the use of numerical taxonomy methods. Further aims were (2) to find and to describe morphotypes within E. repens, and (3) to explain phenetic relationships between them, based on the results of the above analyses. Finally, (4) the taxonomic status of E. repens morphotypes was identified using the results of intraspecific genetic variation given in the authors' previous studies (Szczepaniak et al. 2002, 2009; Szczepaniak and Cieślak 2003).

\section{MATERIAL AND METHODS}

\section{Material}

The taxonomic concept of Elymus repens of Melderis (1978), applied in Flora Europaea (Melderis 1980), was accepted in the present study. According to the concept, only the typical subspecies, E. repens subsp. repens, occurs in Poland. The majority of herbarium specimens deposited in Polish herbaria (BIL, BSG, BYDG, GDMA, KRA, KRAM, KTC, KTU, LBLM, LOD, OLSZ, POZ, SLTC, SZCZ, TRN, UGDA, WA, WRSL, WSRP; acronyms according to Mirek et al. (1997)) were studied to delimit the range of morphological variability and distribution of the species.

Morphometric analyses were conducted on 44 population samples of Elymus repens (each sample comprising 23-30 specimens; 1180 specimens altogether) collected in Poland (Appendix). Sampling was performed in the areas where taxa with epithets: repens, aristatus, subulatus, caesius, and pubescens are thought to occur in Poland (Conert 1998). The prior use of any strict taxonomic rank was defined. The full range of morphological and eco-geographical variations encountered in the species was represented in the study material. The habitats in which E. repens occurred were classified according to Davies et al. (2004). As E. repens reproduces by rhizomes, specimens were chosen at least $6 \mathrm{~m}$ apart to increase the likelihood of picking ramets from different genets. A spatially separated, generative shoot with its own root system was treated as a specimen, even if it showed connections with other shoots through underground organs (cp. Corradini et al. 2002). In natural habitats, specimens were collected from the margins as well as the centre of populations, where accessible. In addition, to standardizing growth factors, rhizome fragments from the same populations (from 5 places along the margin and in the centre of a population) were cultivated under identical environmental conditions in plots in the Botanical Garden of the Jagiellonian University in Kraków, and the variability and stability of morphological characters were observed. Specimens (5-10) from garden plots were collected in the next vegetative season after its planting and all their measurements were included in the multivariate analyses. Voucher specimens from all the study populations were deposited in the herbarium of the W. Szafer Institute of Botany, Polish Academy of Sciences, Kraków (KRAM).

\section{Data analyses}

In morphometric analyses, specimens from populations were treated as Operational Taxonomic Units (OTUs, Stace 1989). As required by the assumptions of numerical taxonomy (Sneath and Sokal 1973), variations of a great number of morphological characters were examined to provide the basis of the intraspecific classification. A set of characters was selected basing on previous taxonomic treatments, the knowledge of characters presumed to differentiate intraspecific taxa (Szafer 1919; Szabó 1981; Prokudin 1982; Kosina 1995; Conert 1998), the authors' field observations and herbarium material analysis. Fully developed and not wasted culms were analyzed. In pre-analysis, morphological characters were not rated or classified according to their importance, and a total of 48 characters were measured and estimated on each specimen (cp. Mizianty et al. 2001). The characters of the lower and upper glumes, the lemma and palea of the lowest flower in the middle spikelet of the spike and characters of the leaf of the middle part of the culm were analyzed. Finally, eleven most informative characters were chosen for evaluation of morphological variation within and between Elymus repens populations (Table 1). Samples were studied and characters were measured using a light microscope Nikon Eclipse E600.

Phenetic relationships among and within intraspecific groups were examined using univariate statistics and multivariate morphometric analyses. The samples of Elymus repens were characterized by univariate statistics of characters: minimum, maximum, arithmetic mean and standard deviation. All characters followed a normal or log-normal distribution, confirmed by Shapiro-Wilk tests (Royston 1982). Characters deviating from the normal distribution were $\log _{10}$ transformed before analyses (Sneath and Sokal 1973). The morphometric data matrix was standardized, i.e. the variation in each character was scaled between 0 and 1. Standardization of variables was used to reduce the effects of different measurement scales for different characters which could then be compared. The complete data matrix can be obtained from the author upon request.

In the first step, Principal Component Analysis (PCA) of the total characters' correlation matrix was used to summa- 
TABLE 1. Characters used in multivariate morphological analyses of Elymus repens.

\begin{tabular}{|c|c|c|}
\hline No. & Abbreviation & Characters \\
\hline & & SPIKE \\
\hline 1 & SPIKLEN & length of the spike \\
\hline \multirow[t]{2}{*}{2} & INTERLEN & length of internode in the middle part of spike \\
\hline & & SPIKELET \\
\hline 3 & SPIKELLEN & $\begin{array}{l}\text { length of the spikelet, without awn (measured from the base of rachilla up to the palea apex of the highest floret of } \\
\text { spikelet) }\end{array}$ \\
\hline \multirow[t]{2}{*}{4} & NOSPIKELFLO & number of florets per spikelet \\
\hline & & LOWER GLUME \\
\hline 5 & LGLULEN & length \\
\hline 6 & LGLUWID & width \\
\hline 7 & LGLULEN / LGLUWID & ratio: length / width $(5 / 6)$ \\
\hline \multirow[t]{2}{*}{8} & LGLUAWN & length of the lower glume awn \\
\hline & & LEMMA \\
\hline 9 & LEMLEN & length \\
\hline 10 & LEMAWN & length of the lemma awn \\
\hline 11 & PALLEN & $\begin{array}{l}\text { PALEA } \\
\text { length }\end{array}$ \\
\hline
\end{tabular}

rize variation in multivariate character space within and among the Elymus repens samples. PCA was used as the ordination method of the population samples studied into some naturally distinguishing groups, without any a priori taxonomic classifications, and was applied to the reduction of the total number of morphological characters. Hence, some characters (i.e. those with the highest values of character loadings) that greatly contributed to the differences among the distinguishing groups of populations and explained the existing variation the best were selected (Sneath and Sokal 1973).

Next, Canonical Discriminant Analysis (CDA; in this analysis more than two categories were tested) was performed to evaluate the respective character importance for the separation of Elymus repens morphotypes (Sneath and Sokal 1973). CDA (with stepwise procedure) was used to determine whether specimens from each distinguished group identified a priori (in contrast to PCA) are efficiently discriminated on the basis of the morphometric character set chosen. CDA is a multivariate technique that determines the linear combination of input variables, maximizing the ratio of variance among groups (morphotypes in this paper) to the variance within groups based on $F$ statistics (Snedecor 1956). The number of discriminant functions that add significantly to the discrimination between groups and a chi-squared test of their significance were assessed. The squared Mahalanobis distances among the groups and a test of significances between centroids was also calculated. The discriminant functions were then used to estimate the percentage of correct specimen classifications into selected intraspecific taxa (Sneath and Sokal 1973). Additionally, a cross-validation, assessing the predictive accuracy of the obtained model in a test sample relative to its predictive accuracy in the learning sample, was performed. For this analysis, 20\% (236) specimens of whole studied material was randomly selected and excluded from the dataset and the discriminant functions were calculated for the remaining species. The 236 excluded specimens of E. repens were then used to evaluate the CDA classification validity by comparing their estimated variety to their true variety (a priori and post hoc predictions).

In order to show the intraspecific variation of Elymus repens, box plots of diagnostic quantitative characters of morphotypes and scatter diagrams of specimens along principal components (PCA) for some, heterogenous population samples, were performed. Finally, non-parametric Kendall tau correlations were counted to express the relationship between the habitat type (according to Davies et al. (2004)) and E. repens morphotypes (Kendall 1975). Numeric analyses of morphometric characters were conducted using STATISTICA, version 8.0 (StatSoft, Inc. 2007).

\section{RESULTS}

\section{Interpopulational morphological variability}

Morphological similarities and differences among population samples were analyzed in PCA based on the total 48 characters' correlation matrix. However, only the results of the next stage of the analyses are shown in the present paper due to the large range of the study material and for the sake of graph clarity. Morphotypes within Elymus repens are distinguished, including particular population samples, but they are not marked individually on the graph.

The PCA showed that eleven generative, structural spike and spikelet characters, with the highest scores by the three first principal components, provide the greatest contribution to explain variation among distinguishing groups within Elymus repens (Table 2). PC1 reflected differences in the overall size and distinguished specimens with large spikes and spikelets from small individuals, with short spikes and small spikelets (Table 2, PCA graph not shown). PC2 separated awned populations from unawned or short-awned ones (Table 2, Fig. 1). Awned individuals can be both small and robust; similarly, unawned populations are also considerably diverse with respect to size. PCA ordination of individuals along the PC1 and PC2 showed a continuous variation pattern without distinguishing clear-cut groups. 


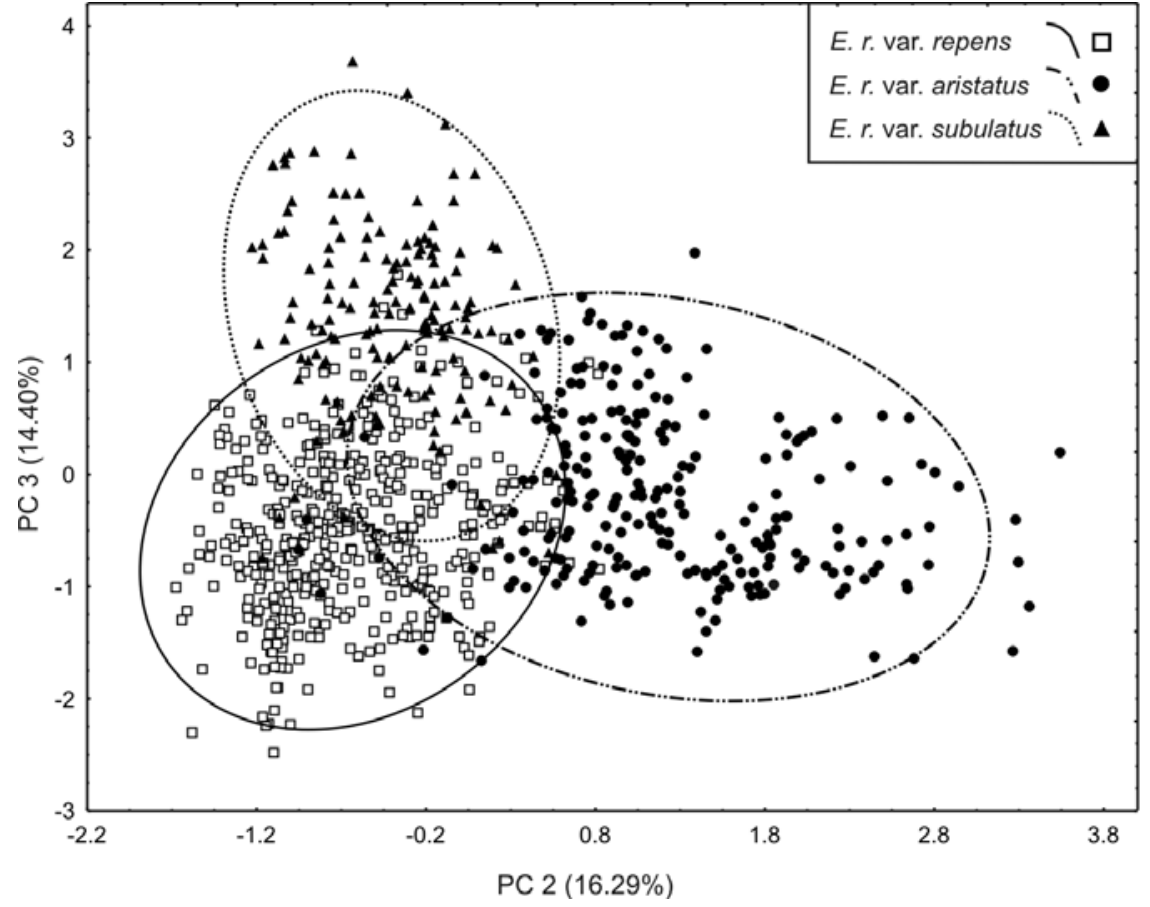

Fig. 1. Principal Component Analysis (PCA) of Elymus repens specimens based on 11 morphological characters (see Table 2). The three intraspecific varieties are delineated by $95 \%$ confidence ellipses.
However, the groups corresponding to the three morphotypes, repens, aristatus and subulatus, are evident on the scatter diagram of the 1180 specimens of E. repens along the PC2 and PC3 (Fig. 1). PC3 distinguished a group of specimens with narrow, elongated glumes (i.g. subulate), unawned or short-awned. There was some overlap among individuals of the three morphotypes in the centre of the scatter diagram, but these morphotypes were displaced in relation to each other, and they had a centre of gravity towards the second and third PCA axis. The first three principal components accounted for $77.62 \%$ (PC1 - 46.93\%; PC2 $-16.29 \%$ and PC3 $-14.40 \%$ ) of the total variance of the character set.

The stepwise procedure of CDA with specimens as OTUs and the morphotypes as groups confirmed the discriminating power of 9 (out of 11) quantitative characters from PCA. Low Wilks' lambda $(=0.1013)$ suggested a re-

TABLE 2. Results of the Principal Component Analysis (PCA) for the specimens of Elymus repens as OTUs - cumulative variance and the 11 morphological characters showing the highest factor loadings on the first three principal component (PC1, PC2, PC3). The bold type marks the high correlations $(r \geq 0.60)$ of characters with principal components. (For character abbreviations see Table 1.)

\begin{tabular}{llccc}
\hline Principal component & PC1 & PC2 & PC3 \\
\hline Cumulative variance \% & 46.93 & 16.29 & 14.40 \\
\hline No. & Character & & Loadings & \\
\hline 1 & SPIKLEN & $\mathbf{0 . 7 6}$ & -0.06 & 0.01 \\
2 & INTERLEN & $\mathbf{0 . 7 4}$ & 0.13 & 0.01 \\
3 & SPIKELLEN & $\mathbf{0 . 8 9}$ & 0.08 & -0.12 \\
4 & NOSPIKELFLO & $\mathbf{0 . 7 4}$ & 0.04 & -0.34 \\
5 & LGLULEN & $\mathbf{0 . 8 8}$ & -0.16 & 0.10 \\
6 & LGLUWID & 0.47 & -0.09 & $-\mathbf{0 . 8 1}$ \\
7 & LGULEN / LGLUWID & 0.42 & -0.08 & $\mathbf{0 . 8 8}$ \\
8 & LGLUAWN & 0.10 & $\mathbf{0 . 9 2}$ & 0.05 \\
9 & LEMLEN & $\mathbf{0 . 9 0}$ & 0.08 & 0.09 \\
10 & LEMAWN & -0.01 & $\mathbf{0 . 9 3}$ & -0.06 \\
11 & PALLEN & $\mathbf{0 . 8 4}$ & 0.08 & 0.04 \\
\hline
\end{tabular}

latively high predictability of tested model. The first two canonical discriminant functions added significantly to the discrimination between groups (chi-squared test for function $1=2684$ and for function $2=1018 ; p<0.001$ ), and they explained $98 \%$ of the total variance in the original data set. Values of partial Wilks' lambda and correlation coefficients showed that the length of lemma's awns was the most discriminating character for the separation of the aristatus group along the first canonical discriminant function, while the shape of glumes separated specimens of subulatus along the second canonical discriminant function (Table 3, Fig. 2). These are the same characters with the highest loadings in PCA. The other characters provided weaker discrimination between $E$. repens morphotypes, but can be used in their description. The length of the lower glume awn and the number of florets in the spikelet do not differentiate E. repens morphotypes. Using CDA, post hoc correct classifications of specimens into repens, aristatus and subulatus groups were at level of $94 \%$ (616 of 654), 93\%

TABLE 3. Canonical Discriminant Analysis (CDA) of specimens of Elymus repens varieties; values of partial Wilks' lambda for the discriminating characters for the varieties; the factor structure coefficients represen the correlations between the characters and the canonical discriminan functions (CAN1, CAN2). The significant differences at $p<0.001, p<$ 0.01 and $p<0.05$ are marked by asterisks $* * *, * *$ and $*$, respectively; ns - non significant: $p>0.05$. (For character abbreviations see Table 1.)

\begin{tabular}{clccc}
\hline No. & Character & $\begin{array}{c}\text { partial } \\
\text { Wilks' lambda }\end{array}$ & CAN1 & CAN2 \\
\hline 10 & LEMAWN & $0.27 * * *$ & 0.93 & -0.11 \\
7 & LGLULEN / LGLUWID & $0.83 * * *$ & -0.13 & -0.90 \\
5 & LGLULEN & $0.92 * * *$ & -0.12 & -0.34 \\
6 & LGLUWID & $0.92 * * *$ & -0.03 & 0.31 \\
1 & SPIKLEN & $0.98 * * *$ & -0.03 & -0.15 \\
11 & PALLEN & $0.99 * * *$ & -0.05 & -0.24 \\
3 & SPIKELLEN & $0.99 * * *$ & -0.04 & -0.14 \\
2 & INTERLEN & $0.99 *$ & 0.00 & -0.14 \\
9 & LEMLEN & $0.99 *$ & -0.04 & -0.32 \\
4 & NOSPIKELFLO & $1.00 \mathrm{~ns}$ & -0.02 & 0.01 \\
8 & LGLUAWN & $1.00 \mathrm{~ns}$ & 0.45 & -0.12 \\
\hline
\end{tabular}




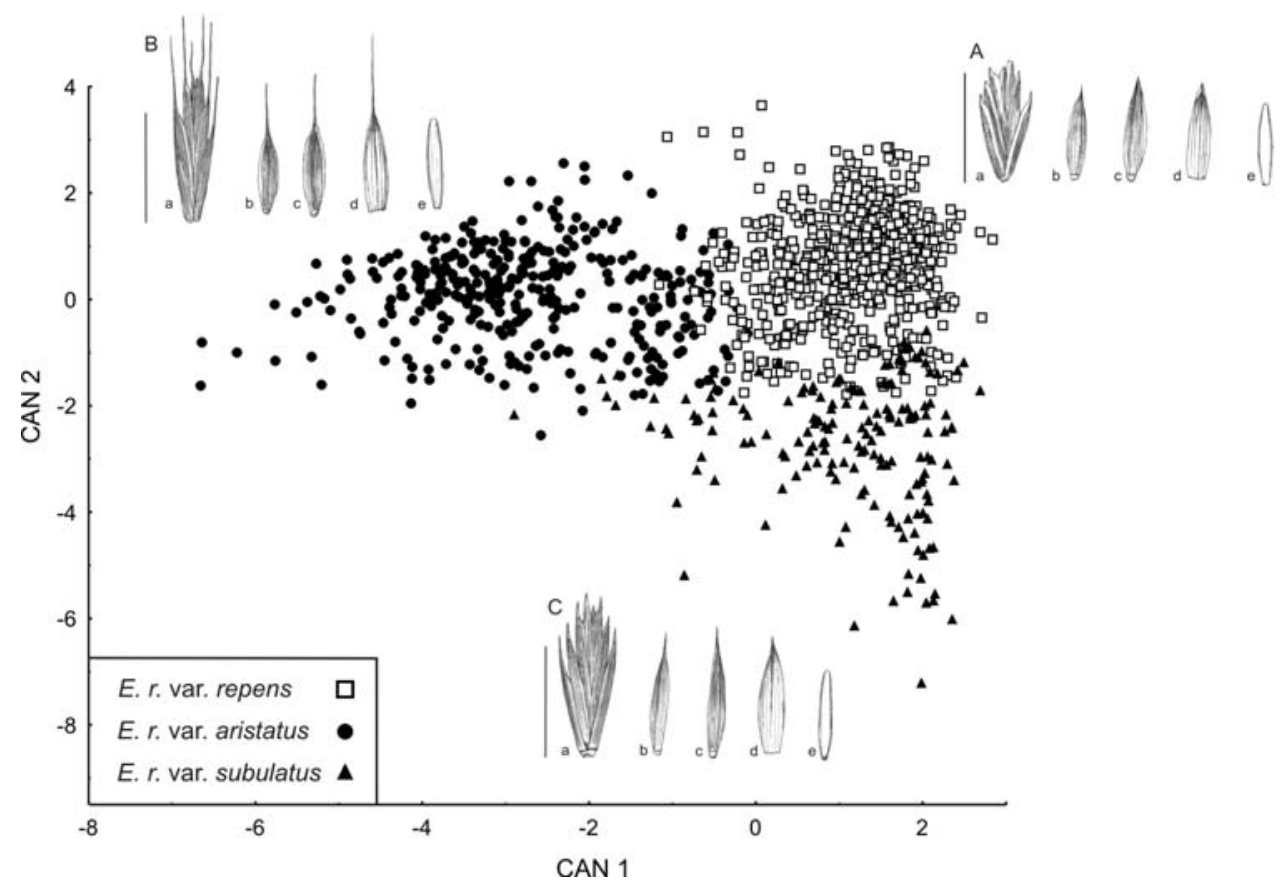

Fig. 2. Canonical Discriminant Analysis (CDA) of Elymus repens specimens as OTUs defined as intraspecific varieties, based on 9 morphological characters (see Table 3). First three canonical discriminant functions explain $98 \%$ of the total variation. Morphological details of E. repens varieties: E. repens var. repens (A), E. repens var. aristatus (B), E. repens var. subulatus $(\mathrm{C})$; spikelet (a), lower glume (b), upper glume (c), lemma (d) and palea (e). Scale bar $=10 \mathrm{~mm}$.

(329 of 353), and 93\% (161 of 173), respectively. Crossvalidation resulted in a reduced classification success from $94 \%$ to $89 \%$ in total, and in details, $96 \%$ of repens specimens (130 of 136), 80\% of aristatus (45 of 56) and 79\% of subulatus (35 of 44) were correctly classified. All squared Mahalanobis distances among the three groups were highly significant $(p<0.001)$. Hence, the repens, aristatus and subulatus morphotypes were distinguished against the mean values of diagnostic characters (Figs 2 and 3). The data therefore support the hypothesis that the morphotypes of $E$. repens are morphologically distinct and could be treated as separate taxa. Additionally, morphometric analyses of the specimens collected in the garden plots showed that discri-

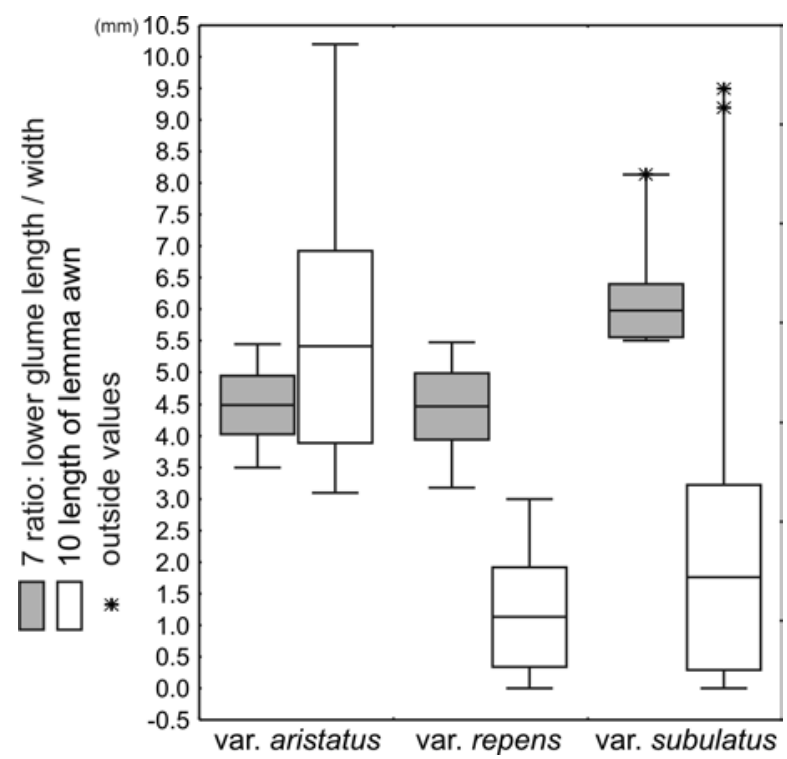

Fig. 3. Diagnostic, morphological characters distinguishing varieties of Elymus repens; means, one standard deviation of the mean and ranges of the length of lemma awn (open box) and the ratio: lower glume length / width (shaded box). Characters were measured for spikelet at the middle part of the spike (see Table 1). minating characters of morphotypes were invariable and therefore they do not depend on ecological conditions such as light, humidity, etc.

The majority of the analysed characters either displayed a weak correlation with a particular habitat type (Kendall tau $r<0.1$ ) or lacked it. The lengths of the culm and the spike, the number of nodes per spike, the length of spike internodes, as well as the leaf length and width, were weakly but significantly correlated $(0.1 \geq r<0.3)$ with the type of habitat. Thus, robust plants with long culms and spikes and with long and wide leaves are more frequent in wet shrubs on rivers and streams, a fairly obvious fact, mostly resulting from background fertility. Aristatus specimens originally inhabited different sites, on dry soil (R-67 and $\mathrm{R}-88$ ) as well as in wet shrubs (R-65; Appendix), but represent the same morphotypes. Similarly, the type entities of repens occurred e.g. on the edge of the forest (R-56) and also along a field (R-86). However, subulatus specimens more often grew within dense and moist scrubs on the rivers and on forest edges, although the other morphotypes also occurred in such sites. The colour of whole plants, the hairiness of leaves and the spike rachis and the leaf length and width were the most variable characters of E. repens. These characters were present in different combinations in plants and did not distinguish any particular morphotypes. The occurrence of individual morphotypes was not significantly correlated with habitat types (Kendall tau $0<r<$ $0.1, p>0.05)$.

\section{Intrapopulational morphological variability \\ - homogenous and heterogenous populations}

A detailed analysis of the range of intrapopulational diversity within Elymus repens was conducted using selected population samples in connection with the total variation range observed. The majority of population samples of $E$. repens were slightly diversified and morphologically homogenous. Specimens from individual populations were scattered within range of variation of repens, aristatus and subulatus morphotypes (PCA graph not shown). 


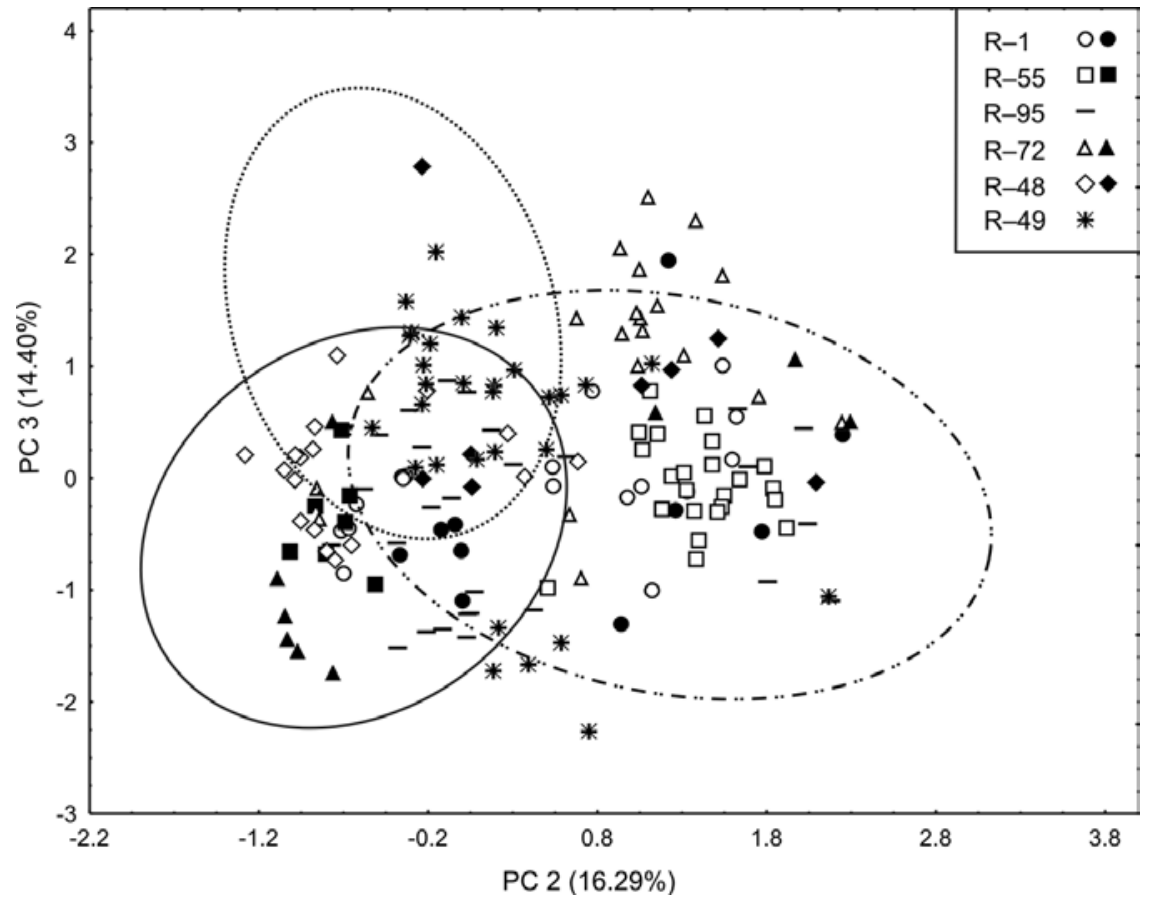

Fig. 4. Principal Component Analysis (PCA) of heterogeneous populations of the Elymus repens based on 11 morphological characters (see Table 2). The three varieties are delineated by $95 \%$ confidence ellipses as given in Figure 1. See Appendix for population abbreviations. Specimens from individual populations with hairless rachis of spike are marked with open symbols; specimens with hairy rachis of spike are marked with filled symbols.
On the other hand, different morphological forms often grow together in the same habitat in Elymus repens populations. Thirteen of the 44 study samples were defined as heterogeneous, which was clearly shown on the PCA scatter diagram (Fig. 4). As the population material examined showed, specimens of repens and aristatus mostly occur together, as observed in the following populations: R-1, R-10, R-16, R-35, R-55, R-64, R-72 and R-95. Population samples R-55 and R-95 were more or less divided into two separate sub-groups on the basis of the lengths of the lower glume awn and the lemma awn that referred to as repens and aristatus morphotypes (Fig. 4, Table 2). More intermediate specimens were found in samples R-1 and R-72. In samples R-8 and R-13, the occurrence of repens and subulatus individuals was confirmed (graph not shown). In samples R-48 and R-49, the three morphotypes of E. repens were distinguished. Likewise, it was shown that specimens of individual samples were differentiated by the hairy rachis, marked by black, filled symbols on scatter diagram (Fig. 4). The hairy rachis was not correlated with other characters and was present in various character combinations in individuals in the same population.

Overall, obtained results showed a relatively continuous pattern of morphological variation of Elymus repens in the geographical scale of Poland. The character sets significantly distinguish the three morphotypes that do not depend on environmental conditions and geographical locations, and often occur in the same habitat. Thus, it is more appropriate to treat these taxa as varieties: E. repens var. repens, var. aristatus and var. subulatus.

\section{DISCUSSION}

\section{Morphological variation versus genetic diversity}

Morphological variation within Elymus repens s. lato is conspicuous and complex, and difficult to interpret taxonomically. Two extremely different plants of this species could be identified as two distinct taxa in the natural habi- tat. The main aim of my study was to determine the efficiency of intraspecific morphotypes distinction using numerical taxonomy.

A large number of morphological characters were scored and numerical methods (PCA and CDA) were applied to examine relationships among Elymus repens morphotypes and to assess the level of intraspecific variation. PCA revealed considerable inter- and intrapopulation morphological variation of E. repens. There are no clear discontinuities between the three separating groups of the population samples studied, but differing, extreme morphotypes can be distinguished. CDA tend to support the recognition of three taxonomic units. However, my results highlight the difficulty with drawing objective limits between those putative taxonomic units. The difficulty arises from the extensive polymorphism found both within and among populations. Unawned or awned lemmas and the shape of glumes are the most important characters supporting clustering of the material into groups (characters no 10 and 7). Other morphological characters are taxonomically not reliable enough, and numerous individuals with intermediate characters and with various combinations of characters exist.

A typical specimen of Elymus repens is characterized by unawned, sharply-pointed glumes, or glumes with rough awns up to $3.5 \mathrm{~mm}$. Specimens of aristatus are distinguished by having long-awned lemmas while those of subulatus have long, subulate glumes with a narrow membraneous margin. The variation ranges of discriminating characters do not overlap and mean values and standard deviation differ among particular taxa. The analysis of the herbarium material showed that long-awned specimens of E. repens were often misclassified as Elymus caninus (L.) L. Previous, detailed morphometric analyses of the representatives of the genus Elymus occurring in Poland displayed an invariable character set that clearly differentiated $E$. caninus from E. repens. The most important character distinguishing these species is the number of veins per glumes: $E$. caninus always has 3 -veined glumes, whereas E. repens is characterized by glumes with more than 3 veins (Mizianty 
et al. 2001). The finding that all long-awned specimens of E. repens have glumes with more than 3 veins was also supported in the present study.

The great morphological variation of Elymus repens can result from its open-pollinated system of mating (Prokudin 1982). Specimens of particular morphotypes can easily crossbreed among themselves or with other representatives of the Triticeae tribe, which can affect diverse patterns of morphological types (Szczepaniak et al. 2007). For example, hybrids between E. repens and Elymus hispidus are relatively common in the field (Melderis 1980; Mahelka et al. 2007) and propagate vegetatively by rhizomes, and at least some gene flow via backcrossing to the parents can be expected. Thus, hybrids often cannot be morphologically identified with certainty due to their great similarity to either E. repens or E. hispidus (Szczepaniak et al. 2007).

Morphological differentiation of clonal species can also be caused by the accumulation of mutation during perennial life of somaclonal genets (Corradini et al. 2002). Elymus repens is a persistent, perennial grass wide creeping by long-lived rhizomes. Populations of this species consist of one or only few genotypes, with high levels of genetic heterogeneity among populations (Szczepaniak and Cieślak 2003). New populations are established by few fragments of rhizomes or seeds, subsequently spreading mostly vegetatively. The germination of E. repens populations is slow, rarely exceeds $50 \%$ of total seeds capable of germination, and seedlings are also little vigorous (Szabó 1979). However, analysis of RAPD variation showed that despite the high importance of vegetative reproduction in E. repens, gene flow between populations and repeated seedling recruitment might be more frequent than commonly considered (Szczepaniak et al. 2009).

Studies conducted on Elymus repens suggest that its abilities of genomic expression into very different phenotypes are considerably greater than genetic diversity (Szabó 1981; Taylor and Aarssen 1988; Szczepaniak et al. 2002; Szczepaniak and Cieślak 2003). E. repens can form physiological ecotypes and exhibits variability along the ecological gradient, but morphological and genetic analysis results did not support the occurrence of a particular morphotype in a given habitat (Brej 2001, Szczepaniak 2002a; Szczepaniak and Cieślak 2003). This species occurs in a continuous series of overlapping habitats in nature, and local populations are genetically adapted to different environmental factors, which is also confirmed by the high genome mobility of E. repens (Kosina 1995; Szczepaniak and Cieślak 2003). Taylor and Aarssen (1988) demonstrated the greater plasticity of genotypic variation within populations of $E$. repens, for some treatments represented a range of important biotic and abiotic conditions that the species may encounter in the field. These authors proved that the older populations of E. repens tended to show a greater degree of plasticity than the younger populations, which may be the consequence of past selection for more plastic genotypes in a variable or unpredictable environment in the former case. An alternative interpretation of greater variance of performance in older populations may state that natural selection favoured genotypes which are specialized to particular environmental conditions (Taylor and Aarssen 1988).

Adaptation abilities of Elymus repens to variable environmental conditions are to some extent genetically predefined (Taylor and Aarssen 1988; Brej 2001). It is a noxious weed, coping with interaction of various factors induced by human weed-control activity. Natural selection favoured more plastic genotypes of E. repens, resulting in the generation of genotypes specific to individual populations that, however, differ at a small number of loci. These small genetic differences guarantee the survival and reproduction progress of a population under particular environmental conditions. Scholz (1993) claims that E. repens originated by hybridization of steppe grasses, and the later diversification of species sensu stricto took place in response to human activity, connected with field cultivation and weed control. Such "homeless" European plants are defined by Scholz (1993) as "indigenophyta anthropogena" that are stimulated to genetic changes unintentionally by artificial changes of habitats.

Genetic variation of Elymus repens assessed by AFLPs markers (Szczepaniak et al. 2002; Szczepaniak and Cieślak 2003), including individuals from the same populations studied morphologically in the present paper, showed the absence of significant genetic differences between morphotypes. Results of the Mantel test in the above studies also revealed that genetic variability was not significantly correlated with morphotypes $(r=-0.58, p>0.13$; Szczepaniak and Cieślak 2003). Prokudin (1982) and Tsvelev (1979) confirm that the morphology of E. repens is not affected by ecological and geographic conditions. E. repens is a species of a wide ecological amplitude, and conspicuous morphological differentiation can be caused by intensive evolution processes occurring within it.

\section{Taxonomic implications}

A critical assessment of intraspecific variation and its expression in taxonomic categories are required to provide an appropriate name of a taxon, and to draw attention to its separate position (Stace 1989). Moreover, hypotheses concerning migration roads and present-day diversification of taxa may be formulated basing on character variation analysis, especially if a restricted study area is considered (Grundt et al. 2001). The use of intraspecific categories has varied greatly and various definitions have been applied (Stace 1989; Hamilton and Reichard 1992; Grundt et al. 2001).

Overall, the present results showed a intricate pattern of morphological variation of Elymus repens in Poland. Character sets significantly distinguish three morphotypes that do not depend on ecological conditions and geographical locations, and often occur in the same habitat. Additionally, the low level of intraspecific genetic differentiation (Szczepaniak et al. 2002; Szczepaniak and Cieślak 2003) indicates a wide species circumscription. It is therefore appropriate to treat these intraspecific taxa as varieties: $E$. repens var. repens, var. aristatus and var. subulatus due to the morphological, ecological and genetic variation pattern. This treatment corresponds with the criterion of variety naming as defined in the International Code of Botanical Nomenclature by Du Rietz (1930): it is "a population of one or several biotypes, forming a more or less distinct local facies of a species" (according to Stace 1989). The entities defined as var. caesium and var. pubescens in the previous taxonomic treatment could not be recognized in multivariate analyses. The characters used to determine these varieties appear in many combinations with other characters of E. repens individuals. Thus, I suggest that only the pube- 
scens form, E. repens var. repens f. pubescens, E. repens var. aristatus f. pubescens, E. repens var. subulatus f. pubescens, should be proposed on the basis of the presence of the hairy spike rachis in all the varieties.

Based on the original biometric study of the Polish material, I propose the following key to distinguish the three varieties of Elymus repens.

\section{Key to the varieties of Elymus repens}

1. Glumes up to $3 / 4$ of the spikelet's length, lanceolate to lanceolate-oblong, awned or unawned, with wide membraneous margin

2. Lemmas acute, unawned or with awn up to $3 \mathrm{~mm}$ length. E. repens var. repens

$2^{*}$. Lemmas acute with awn from 3 to $10 \mathrm{~mm}$ length .................................... . repens var. aristatus

$1 *$ Glumes up to above 3/4 of the spikelet's length and/or enclose almost whole spikelet, subulate, elongate, with narrow membraneous margin, unawned or with short awn

E. repens var. subulatus

\section{Taxonomy and nomenclature of Elymus repens varieties}

\section{Elymus repens (L.) Gould,}

\section{Madrońo 9(4): 127 (1947) var. repens}

Lectotype: "Habitat in Europae cultis", Linnaean herbarium no. 104/7 (LINN). Lectotype designated by Bowden (1965).

Synonyms: Triticum repens L., Sp. pl. 1: 86 (1753); Zeia repens (L.) Lunell, Amer. Midl. Naturalist 4: 227 (1915); Agropyron repens (L.) P. Beauv., Ess. Agrostogr. 102 (1812); Elytrigia repens (L.) Desv. ex Nevski, Trudy Bot. Inst. Akad. Nauk SSSR, ser. 1, Fl. Sist. Vyssh. Rast. 1: 14 (1933).

Perennial, forming extensive, wiry rhizomes, creating thick and stout net. Culm: up to $170 \mathrm{~cm}$ (100), erect, stout, smooth, with 3-7 (5) nodes. Leaf: blade: dull green or bluish-greyish-green, 3.0-12.0 mm (6.0) wide, flat, sometimes slightly convolute on the margins in plants growing in dry habitat, with slightly prominent and very scabrid veins, hairless, rarely with sparse long hairs on the adaxial surface, glabrous on the abaxial surface with more prominent veins, shiny; sheath: open, hairless in the upper part of culm and always very densely pubescent in the lower part, with overlapping auricles; ligule: 0.2-0.8 mm (0.4) long, dentate, membranous. Spike: erect, 4.8-19.5 cm (11.0) long, stiff, equally dense except the more lax part at its base; rachis: tough, with 10-31 (18) nodes, very rough on the margins, usually hairless, sometimes pubescent, spikelets in the middle part of spike usually $2.5 \times$ longer than associated internode (sometimes in specimens with very dense spike, where spikelets are almost $5 \times$ longer than associated internode). Spikelet: sessile, 7.0-19.0 mm (13.0) long, 2-8 (4)flowered, solitary, rarely double or triple on the spike's node, hairless, at maturity disarticulating below glumes, sometimes reddish or with waxy covering; rachilla: widening toward the apex, with marked groove on the apex, minutely hairy; glumes: similar, nearly equal; lower glume: 5.5$12.7 \mathrm{~mm}$ long, $1.0-3.0 \mathrm{~mm}$ wide $(8.5 \times 1.9)$; upper glume: 5.5-13.5 mm long, $1.1-2.8 \mathrm{~mm}$ wide $(9.0 \times 2.0)$, lanceolate to lanceolate-oblong, acute, unawned or with rough awn up to 3.5 (1.1) $\mathrm{mm}$, with wide membraneous margin, usually up to $3 / 4$ of the length of the spikelet, hairless, with 3-7 (5) rough veins and prominent central keel, sometimes veins are breaking off, but always convergent at the tip; lemma: 6.0-12.5 mm (9.5) long and 1.7-3.8 $\mathrm{mm}$ (2.6) wide, widelanceolate, sharply pointed, awnless or with awn up to 3.0 (1.0) $\mathrm{mm}$, shiny, hairless, convex, 5-veined; palea: 5.8-10.0 (8.0) $\mathrm{mm}$ long and 1.0-2.6 (1.3) $\mathrm{mm}$ wide, rounded or slightly concave, ciliate on veins up to about $3 / 4$ of its length, fine, distinctly shorter than lemma. Chromosome number $2 \mathrm{n}=28$ (own studies: population R-56; Singh 1964; Mizianty et al. 2001) and $2 \mathrm{n}=42$ (own studies: populations R-33 and R-78; Bowden 1965; Mizianty et al. 2001).

\section{Elymus repens (L.) Gould var. aristatus (Schreb. ex Baumg.) Melderis and D.C. McClint.}

D. McClintock, Suppl. Wild Flow. Guernsey 48.1987

Basionym: Agropyron repens var. aristatum Schreb. ex Baumg., Enum. Stirpium Transs. 3: 269 (1816).

Synonyms: Triticum repens var. aristatum Döll, Fl. Gross. Baden 128 (1855), hom. illeg.; Elytrigia repens var. aristata Prokudin, Proc. Bot. Inst. Kharkov 3: 189 (1938); Triticum repens var. aristatum Schumach., Enum. Pl. Part. Saell. Septentr. Orient. 1: 38 (1801); Agropyron repens fo. aristatum (Schumach.) Holmb.; Hart. Handb. Skand. Fl. 2: 274 (1926) - nom. illeg., non Agropyron repens var. aristatum Schreb. ex Baumg. (1816); Elytrigia repens fo. aristatum (Schumach.) Beetle, Phytologia 55(3): 211 (1984) nom. illeg., non Elytrigia repens var. aristata Prokudin (1938)

The variety similar to typical, distinguished by having clearly awned glumes and lemmas. Glumes: similar, nearly equal; lower glume: $4.9-11.0 \mathrm{~mm}$ long, $1.1-2.5 \mathrm{~mm}$ wide $(8.5 \times 1.8)$; upper glume: $5.2-11.3 \mathrm{~mm}$ long, $1.1-2.8 \mathrm{~mm}$ wide $(9.0 \times 2.0)$, lanceolate, acute with awn up to $6.0(2.7)$ $\mathrm{mm}$, with membraneous margin, usually up to $3 / 4$ of the length of the spikelet, hairless, with 3-7 (5) rough veins; lemma: 6.9-13.0 mm (9.6) long and 1.7-3.7 mm (2.6) wide, wide-lanceolate, sharply pointed, with rough awn from 3.0 up to $10.0(5.4) \mathrm{mm}$, shiny, hairless, convex, 5-veined; palea: 5.5-10.0 (8.1) $\mathrm{mm}$ long and 1.0-2.6 (1.3) mm wide, rounded or slightly concave, ciliate on veins, shorter than lemma. Chromosome number $2 \mathrm{n}=42$ (own studies, population R-67 from Gorzędziej near Tczew, on the Vistula river).

Elymus repens (L.) Gould var. subulatus (Roem. and Schult.) Szczepaniak, comb. nova

Basionym: Agropyron repens var. subulatum Roem. and Schult., Syst. Veget. 2: 754 (1817).

Synonyms: Triticum repens var. subulatum (Roem. and Schult.) Nees, Fl. Brasil. Enum. Pl. 2: 450 (1829); Elytrigia repens var. subulatum (Roem. and Schult.) Prokudin, Trudy Naucho-Issledovatel'skogo Inst. Bot., Kharkiv. Derzhav. Univ. Gor'kogo 3: 189 (1938); Triticum subulatum Schreb. ex Schweigg. and Körte, Fl. Erlang., ser. 2, 1: 143 (1811) - nom. illeg., non Triticum subulatum Banks and Sol. in Russell (1794); Elytrigia repens (L.) Nevski var. subulatum (Roem. and Schult.) Seberg and G. Petersen, Bot. Jahrb. Syst. 120(4): 538 (1998) - nom. illeg., non Elytrigia repens var. subulatum (Roem. and Schult.) Prokudin (1938)

The variety distinguished from typical by subulate glumes and larger spikelets, somewhat longer and narrower lemmas, paleas and glumes; glumes are almost equal to the 
length of the spikelet. Glumes: similar, nearly equal; lower glume: $6.5-12.2 \mathrm{~mm}$ long, 1.1-2.0 mm wide $(9.9 \times 1.7)$, upper glume: 7.2-13.6 mm long, 1.2-2.8 mm wide $(10.4 \times$ $1.9)$, subulate, gradually narrowing from the middle towards to the apex, acute, unawned or with awn up to 5.0 (1.5) $\mathrm{mm}$, with narrow, convolute membranous margin, hairless, with 3-7 (5) rough veins, always enclose almost whole spikelet; lemma: 8.0-13.0 mm (10.7) long and 1.7$-3.1 \mathrm{~mm}$ (2.6) wide, lanceolate, sharply pointed, unawned or with rough awn up to $9.5(1.8) \mathrm{mm}$, shiny, hairless, convex, 5-veined; palea: 6.6-10.1 (8.8) $\mathrm{mm}$ long and 1.0-2.1 (1.3) $\mathrm{mm}$ wide, rounded, ciliate on veins, shorter than lemma. Chromosome number $2 \mathrm{n}=42$ (own studies, population R-69 from the Hel Peninsula).

\section{ACKNOWLEDGEMENTS}

I would like to thank Professor Marta Mizianty for the valuable comments on the earlier versions of the manuscript. I thank also to the Institutes supplying the plant material. This work was supported by the Polish Ministry of Education and Science, grant no. 6 P04C 07619.

\section{LITERATURE CITED}

BOWDEN W.M. 1965. Cytotaxonomy of the species and interspecific hybrids of the genus Agropyron in Canada and neighbouring areas. Can. J. Bot. 43: 1421-1448.

BREJ T. 2001. Ecological significance of assimilate distribution in Agropyron repens clones under influence of the copper smelter Legnica. Acta Soc. Bot. Pol. 2: 145-151.

CONERT H.J. (ed.). 1998. Gustav Hegi Illustrierte Flora von Mitteleuropa. Spermatophyta: Angiospermae: Monocotyledones 1 (2), Poaceae. Band I, teil 3. Parey Buchverlag, Berlin, $928 \mathrm{pp}$.

CORRADINI P., EDELIN C., BRUNEAU A., BOUCHARD A. 2002. Architectural and genotypic variation in the clonal shrub Taxus canadensis as determined from random amplified polymorphic DNA and amplified fragment length polymorphism. Can. J. Bot. 80: 205-219.

DAVIES C.E., MOSS D., HILL M.O. 2004. EUNIS habitat classification revised 2004. Report to the European Environment Agency, European Topic Centre on Nature Protection and Biodiversity, $311 \mathrm{pp}$.

DU RIETZ G.E. 1930. The fundamental units of biological taxonomy. Svensk Bot. Tidskr. 24: 333-428.

FALKOWSKI M. (ed.). 1982. Trawy polskie (Polish grasses). Państwowe Wydawnictwo Rolnicze i Leśne, Warszawa, 565 pp. (in Polish).

FERNALD M.L. 1933. Recent discoveries in the Newfoundland flora. Rhodora 35: 167-185.

GRUNDT H.H., BORGEN, L., ELVEN R. 2001. Infraspecific variation in Cerastium alpinum s. lat. (Caryophyllaceae) in Central Norway. Nord. J. Bot. 20: 641-653.

HAMILTON C.W., REICHARD S.H. 1992. Current practice in the use of subspecies, variety, and forma in the classification of wild plants. Taxon 41 (3): 485-498.

HANSEN A. 1959. Die Elytrigia-Arten und -Hybriden an der polnischen Ostseeküste. Fragm. Flor. Geobot. 5 (2): 182-189.

HOLM L.G., PLUCKNETT D.L., PANCHO, J.V., HERBERGER J.P. 1977. The world's worst weeds: distribution and biology. University Press of Hawaii, Honolulu, 609 pp.

HULTÉN E., FRIES M. 1986. Atlas of North European vascular plants. North of the Tropic of Cancer. 1. 498 pp.; 3. 1172 pp. Koelz Scientific Books, Königstein.
KENDALL M.G. 1975. Rank correlation methods. 4th Ed. Charles Griffin, London, 202 pp.

KONDRACKI J. 1981. Geografia fizyczna Polski (Physical geography of Poland). PWN, Warszawa, 463 pp. (in Polish).

KOSINA R. 1995. Comments on the variation of spike morphology in selected species of Elytrigia and Elymus (Triticeae). Acta Soc. Bot. Pol. 64 (4): 385-392.

LÖVE Á. 1984. Conspectus of the Triticeae. Feddes Repert. 95 (7-8): 425-521.

MAHELKA V., FEHRER J., KRAHULEC F., JAROLÍMOVÁ V. 2007. Recent natural hybridization between two allopolyploid wheatgrass (Elytrigia, Poaceae): ecological and evolutionary implications. Ann. Bot. 100 (2): 249-260.

MASON-GAMER R.J. 2004. Reticulate evolution, introgression, and intertribal gene capture in allohexaploid grass. Syst. Biol. 53 (1): 25-37.

MATUSZKIEWICZ W. 2005. Przewodnik do oznaczania zbiorowisk roślinnych Polski. Wyd. 3. (A guide to identification of plant communities of Poland. 3rd Ed.). PWN, Warszawa, 537 pp. (in Polish).

MELDERIS A. 1978. Taxonomic notes on the tribe Triticeae (Gramineae), with special reference to the genera Elymus L. sensu lato, and Agropyron Gaertner sensu lato. In: Flora Europaea Notulae Systematicae ad Floram European spectantes No. 20. Heywood V.H. (ed.). Bot. J. Linn. Soc. 76 (4): 369-384 .

MELDERIS A. 1980. Elymus L. In: Flora Europaea. 5. Alismataceae to Orchidaceae (Monocotyledones). Tutin T.G., Heywood V.H., Burges N.A., Moore D.M., Valentine D.H., Walters S.M., Webb D.A. (eds). Cambridge University Press, Cambridge, pp. 192-198.

MIREK Z., MUSIAŁ L., WÓJCICKI J.J. 1997. Polish herbaria. Polish Bot. Stud. Guideb. Ser. 18: 1-116.

MIZIANTY M., FREY L., SZCZEPANIAK M. 2001. The Agropyron-Elymus complex (Poaceae) in Poland: biosystematics. In: Studies on grasess in Poland. Frey L. (ed.). W. Szafer Institute of Botany, Polish Academy of Sciences, Kraków, pp. 25-77.

PROKUDIN YU.N. 1982. The results of composite biosystematical study of Elytrigia repens (Poaceae). Bot. Zhurn. 67 (2): 129-139. (in Russian with English summary).

ROSTAFIŃSKI J. 1873 (“1872”). Florae polonicae prodromus. Verh. k. k. zool.-bot. Ges. Wien.: 81-208.

ROTHMALER W. 1994. Excursionsflora von Deutschland. Band 4. G. Fischer Verlag, Jena-Stuttgart, $811 \mathrm{pp}$.

ROYSTON J.P. 1982. An extension of Shapiro and Wilk's W test for normality to large samples. App. Statistics 31: 115-124.

RUTKOWSKI L. 1998. Klucz do oznaczania roślin naczyniowych Polski niżowej. Wydawnictwo Naukowe PWN, Warszawa, 812 pp. (in Polish).

SCHOLZ H. 1993. Elytrigia arenosa (Gramineae) - ein mitteleuropäischer Relikt-Endemit. Bot. Jahrb. Syst. 115 (3): 351-366.

SINGH D.N. 1964. Cytological studies in the Gramineae. III. Sci. and Cult. 30 (8): 396-397.

SNEATH P.H., SOKAL R.R. 1973. Numerical taxonomy. W.H. Freeman, San Francisco, xv +573 pp.

SNEDECOR G.W. 1956. Statistical methods. 5th Ed. Iowa University Press, Ames, $267 \mathrm{pp}$.

STACE C.A. 1989. Plant Taxonomy and Biosystematics. 2nd Ed. Chapman and Hall Inc., New York, 264 pp.

STATSOFT, INC. 2007. Statistica (data analysis software system), version 8.0. www.statsoft.com.

SZABÓ A.T. 1979. Wheatgrass variability (Agropyron, sect. Elytrigia) in a native collection from Transylvania, Romania. I. Agropyron intermedium complex. Not. Bot. Hort. Agrobot. Cluj-Napoca Inst. Agron. "Dr. Petru Groza" 10: 89-99.

SZABÓ A.T. 1981. Wheatgrass variability (Agropyron, sect. Elytrigia) in a native collection from Transylvania. II. Agropyron repens (L.) P. Beauv. Not. Bot. Hort. Agrobot. Cluj-Napoca Inst. Agron. "Dr. Petru Groza" 11: 61-68. 
SZAFER W. 1919. Rodzina Gramineae, Trawy (Family Gramineae, Grasses). In: Flora polska. Rośliny naczyniowe Polski i ziem ościennych. 1. Paprotniki, iglaste i jednoliścienne (Polish flora. Vascular plants of Poland and adjacent territories. 1. Pteridophyta, Coniferae and Monocotyledones). Raciborski M., Szafer W. (eds). Akademia Umiejętności, Kraków, pp. 230-365. (in Polish).

SZCZEPANIAK M. 2002a. Morphological variability of Polish populations of Elymus repens from various habitats - preliminary report. Ecol. Questions 2: 159-168.

SZCZEPANIAK M. 2002b. Biosystematyka Elymus repens (L.) Gould i Elymus hispidus (Opiz) Melderis w Polsce (Biosystematics of Elymus repens (L.) Gould and Elymus hispidus (Opiz) Melderis in Poland). PhD thesis, W. Szafer Institute of Botany, Polish Academy of Sciences, Kraków, Poland, 181 pp. (in Polish),

SZCZEPANIAK M., CIEŚLAK E. 2003. Assessment of genetic variation in Elymus repens and E. hispidus using AFLP markers and its implications for intraspecific taxonomy. In: Problems of grass biology. Frey L. (ed.). W. Szafer Institute of Botany, Polish Academy of Sciences, Kraków, pp. 271-286.

SZCZEPANIAK M., CIEŚLAK E., BEDNAREK P.T. 2002. Morphological and AFLP variation of Elymus repens (L.) Gould (Poaceae). Cell. Mol. Biol. Letters 7 (2A): 547-558.
SZCZEPANIAK M., CIEŚLAK E., BEDNAREK P.T. 2007. Natural hybridization between Elymus repens and Elymus hispidus assessed by AFLP analysis. Acta Soc. Bot. Pol. 76 (3): 225-234.

SZCZEPANIAK M., BIENIEK W., BOROŃ P., SZKLARCZYK M., MIZIANTY M. 2009. A contribution to characterization of genetic variation in some natural Polish populations of Elymus repens (L.) Gould and Elymus hispidus (Opiz) Melderis (Poaceae) as revealed by RAPD markers. Pl. Biol. 11: (Accepted). DOI: $10.1111 /$ j.1438-8677.2008.00171.x

TAYLOR D.R., AARSSEN L.W. 1988. An interpretation of phenotypic plasticity in Agropyron repens (Gramineae). Amer. J. Bot. 75(3): 401-413.

TSVELEV N.N. 1979. On some species of Koeleria Pers. and the origin of Koeleria grandis Bess. ex Gorski (Poaceae). Bot. Zhurn. 64: 985-988. (in Russian with English summary).

TSVELEV N.N. 1984. Grasses of the Soviet Union. Part 1. A.A. Balkema, Rotterdam, $568 \mathrm{pp}$.

ZAJĄC A., ZAJĄC M. (eds). 2001. Atlas rozmieszczenia roślin naczyniowych w Polsce. Distribution Atlas of Vascular Plants in Poland. Edited by Laboratory of Computer Chorology, Institute of Botany, Jagiellonian University, Kraków, 714 pp. (in Polish with English summary). 


\title{
APPENDIX
}

Collection data for the 44 sampled populations of Elymus repens. $\mathrm{N}$ - number of specimens used in morphological analysis. Habitat types with code according to EUNIS habitat classification (Davies et al. 2004): 1 - coastal dunes and sandy shores (B1); 2 - sandy inland habitats and Pinus sylvestris lowland woods (G3.4); 3 - constructed, industrial and other artificial habitats (J); 4 - at the edge along regularly or recently cultivated agricultural habitats (I1); 5 deciduous woodland with Betula, Populus tremula or Sorbus aucuparia (G1.9) and termophilous woodland (G1.7); 6 - wet sites on the rivers and streams in riparian woodland (G1.1); 7 - dry grasslands (E1).

\begin{tabular}{lllr}
\hline $\begin{array}{l}\text { Taxon / } \\
\text { population abbreviation }\end{array}$ & Geographic area1: locality & $\begin{array}{l}\text { Latitude (N) / } \\
\text { longitude (E) }\end{array}$ & N Habitat types \\
\hline
\end{tabular}

\begin{tabular}{l} 
E. repens var. aristatus \\
R-31 \\
R-35 \\
R-57 \\
R-60 \\
R-65 \\
R-67 \\
R-75 \\
R-88 \\
R-106 \\
\hline E. repens var. repens \\
R-7 \\
R-11 \\
R-32 \\
R-33 \\
R-56 \\
R-61 \\
R-63 \\
R-71 \\
R-73 \\
R-78 \\
R-81 \\
R-86 \\
R-89 \\
R-91 \\
R-94 \\
R-101 \\
\hline
\end{tabular}

$\begin{array}{ll}\text { the Southern Wielkopolska Lowland: Czaple Wolne near Kluczbork } & 50^{\circ} 59^{\prime} / 18^{\circ} 08^{\prime}, \\ \text { the Szczecin Coastline: Szczecin } & 53^{\circ} 26^{\prime} / 14^{\circ} 34^{\prime}, \\ \text { ML: Mniszew } & 51^{\circ} 51^{\prime} / 21^{\circ} 18^{\prime}, \\ \text { ML: Błonie near Łęczyca } & 52^{\circ} 05^{\prime} / 19^{\circ} 08^{\prime} \\ \text { PLD: Krąg near Starogard Gdański } & 54^{\circ} 01^{\prime} / 18^{\circ} 27^{\prime} \\ \text { PLD: Gorzędziej near Tczew } & 54^{\circ} 02^{\prime} / 18^{\circ} 50^{\prime} \\ \text { LU: Józefów near Zamość } & 50^{\circ} 29^{\prime} / 23^{\circ} 04^{\prime} \\ \text { the Lithuanian Lake District: Stary Folwark } & 54^{\circ} 05^{\prime} / 23^{\circ} 05^{\prime} \\ \text { NB: Smoniowice near Miechów } & 50^{\circ} 17^{\prime} / 20^{\circ} 14^{\prime}\end{array}$

$\begin{array}{ll}25 & 4 \\ 25 & 2 \\ 25 & 4 \\ 30 & 6 \\ 28 & 6 \\ 30 & 2 \\ 25 & 2 \\ 25 & 6 \\ 25 & 4\end{array}$

\author{
SB: Sandomierz \\ LU: Głębokie near Chełm \\ SL: Mazurowice near Środa Śląska \\ the Lubuskie Lake District: Ługów near Świebodzin \\ KU: Suchedniów near Skarżysko Kamienna \\ TE: Raciążek near Toruń \\ MLD: on the Szeląg Wielki lake near Ostróda \\ KC: Gąski \\ the Wielkopolska Lake District: Mieszków near Jarocin \\ LU: Udrycze near Zamość \\ VU: Gródek on the Bug river \\ PL: Dubiny near Hajnówka \\ PL: Grajewo \\ ML: Głuchów near Grójec \\ SL: Gipsowa Góra near Dzierżysław \\ the Western Pomeranian Lake District: Cedynia
}

$50^{\circ} 41^{\prime} / 21^{\circ} 45^{\prime}$,
$51^{\circ} 17^{\prime} / 23^{\circ} 07^{\circ}$,
$51^{\circ} 13^{\prime} / 16^{\circ} 27^{\prime}$
$52^{\circ} 16^{\prime} / 15^{\circ} 30^{\prime}$
$51^{\circ} 03^{\prime} / 20^{\circ} 50^{\prime}$
$52^{\circ} 51^{\prime} / 18^{\circ} 48^{\prime}$,
$53^{\circ} 42^{\prime} / 20^{\circ} 06^{\prime}$
$54^{\circ} 14^{\prime} / 15^{\circ} 55^{\prime}$,
$52^{\circ} 01^{\prime} / 17^{\circ} 28^{\prime}$
$50^{\circ} 18^{\prime} / 23^{\circ} 16^{\prime}$
$50^{\circ} 48^{\prime} / 23^{\circ} 58^{\prime}$,
$52^{\circ} 47^{\prime} / 23^{\circ} 35^{\prime}$,
$53^{\circ} 39^{\prime} / 22^{\circ} 27^{\prime}$
$51^{\circ} 55^{\prime} / 20^{\circ} 51^{\prime}$,
$50^{\circ} 03^{\prime} / 17^{\circ} 59^{\prime}$,
$52^{\circ} 51^{\prime} / 14^{\circ} 12^{\prime}$
E. repens var. subulatus
$\mathrm{R}-14$
$\mathrm{R}-46$
$\mathrm{R}-47$
R-69
R-70
R-99
SB: Księżpol near Biłgoraj
GC: Rzucewo on the Zatoka Pucka Bay
the Lower Vistula Valley: Dolna Grupa near Grudziądz
GC: the Hel Peninsula, between Jastarnia and Chałupy
KC: Maszewo Lęborskie
the Tatra Mts.: the Dolina Strążyska Valley

\begin{tabular}{lll}
$50^{\circ} 25^{\prime} / 22^{\circ} 44^{\prime}$, & 27 & 6 \\
$54^{\circ} 42^{\prime} / 18^{\circ} 28^{\prime}$ & 25 & 1 \\
$53^{\circ} 29^{\prime} / 18^{\circ} 39^{\prime}$ & 25 & 2 \\
$54^{\circ} 36^{\prime} / 18^{\circ} 48^{\prime}$ & 27 & 1 \\
$54^{\circ} 28^{\prime} / 17^{\circ} 42^{\prime}$ & 25 & 5 \\
$49^{\circ} 16^{\prime} / 19^{\circ} 56^{\prime}$ & 25 & 7 \\
\hline
\end{tabular}

Heterogeneous populations (with two or three varieties)

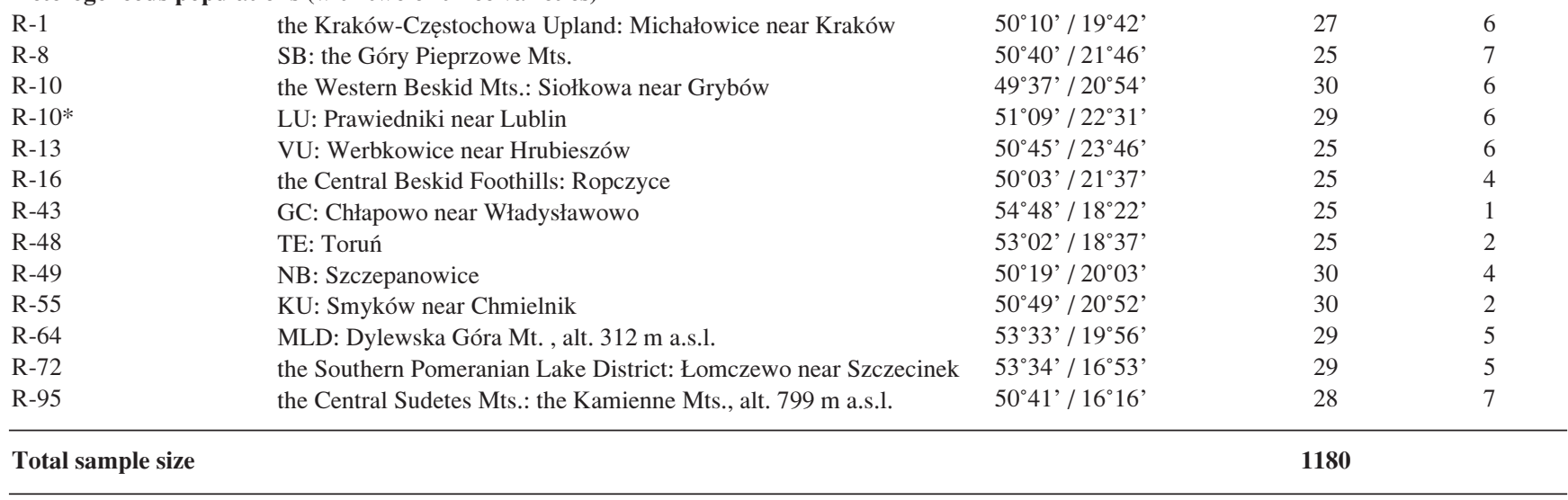

${ }^{1}$ Geographic area (according to Kondracki (1981): GC - the Gdańsk Coastline, KC - the Koszalin Coastline, MLD - the Mazurian Lake District, PLD the Eastern Pomeranian Lake District, TE - the Torun-Eberswalde proto-valley, ML - the Central Mazovian Lowland, PL - the Northern Podlasie Lowland, SL - the Silesian Lowland, NB - the Niecka Nidziańska Basin, SB - the Sandomierz Basin, KU - the Kielce Upland, LU - the Lublin Upland, VU the Western Volhynia Upland. 